Report

\title{
New geochemical data for back-arc basin basalts from DSDP Leg 58 Sites 442-444 and the ODP Leg 131 Site 808, Shikoku Basin
}

\section{Satoru Haraguchi ${ }^{1}$, Koichiro Fujinaga ${ }^{2,3}$, Kentaro Nakamura ${ }^{3}$, Yasuhiro Kato ${ }^{1,2,3}$, Asuka Yamaguchi $i^{4}$ and Teruaki Ishii ${ }^{5}$}

Received February 21, 2018

Accepted May 10, 2018

Japan Agency for Marine-earth Science and Technology (JAMSTEC), 2-15 Natsushima-cho, Yokosuka, Kanagawa 237-0061, Japan

2 Ocean Resources Research Center for Next Generation, Chiba Institute of Technology, 2-17-1 Narashino, Chiba 275-0016, Japan

3 School of Engineering, The University of Tokyo, 7-3-1 Bunkyo, Tokyo 113-8656, Japan

4 Atmosphere and Ocean Research Institute, University of Tokyo, Kashiwanoha 5-1-5, Kashiwa, Chiba 277-8564, Japan

5 Center for Integrated Research and Education of natural Hazards, Shizuoka University, Shizuoka 422-8529, Japan

Corresponding author: S. Haraguchi, s-haraguchi@jamstec.go.jp

\begin{abstract}
Back-arc basin basalts from the Shikoku Basin were recovered at DSDP Leg 58 Sites 442-444 and ODP Leg 131 Site 808. The geochemistry of these volcanic rocks was initially reported soon after their recovery (from the 1980s to the early 1990s), and therefore many of these data suffered from limits of accuracy inherent in data at the time. We reanalyzed archived samples of Sites 442-444 and 808 using recent analytical techniques of XRF and ICP-MS and reported these highly accurate results herein.
\end{abstract}

Keywords: Shikoku Basin, back-arc basin basalt, DSDP Leg 58 Site 442-444, ODP Leg 131 Site 808, recent analytical technique

\section{Introduction}

The Shikoku Basin is a back-arc basin that is located to the west of the Izu-Ogasawara (Bonin) arc (Fig. 1); spreading from 25 to $15 \mathrm{Ma}$ (e.g., Okino et al., 1999). Back-arc basin basalt (BABB) from the Shikoku Basin was recovered during the Deep Sea Drilling Project (DSDP), Ocean Drilling Program (ODP), and International Ocean Discovery Program (IODP). Basement rocks were recovered at Sites 442, 443 and 444, all of which are located at the central Shikoku Basin, during DSDP Leg 58, between December 1977 to January

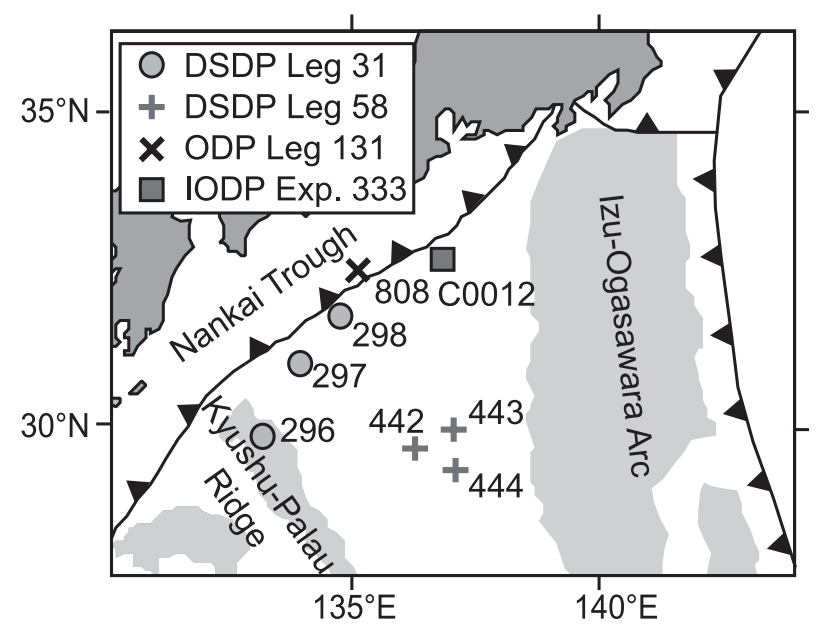

Fig. 1. Location map of the Shikoku Basin region with DSDP and ODP sites indicated. The locations of DSDP Leg 31 and IODP Exp. 333 are also included.

1978 (e.g., Klein and Kobayashi., 1980), and at Site 808, southeast of the Kyushu Island, during the ODP Leg 131, from March to June 1990, and ODP Leg 196, from May to July 2001 (e.g., Shipboard Scientific Party, 1991) (Fig. 1). The initial geochemical analyses of these basement rocks were predominantly reported by proceedings concerning these legs. Due to the fact that these analyses were performed several decades ago, many of the techniques and instruments that were used differ greatly from current approaches, specifically in terms of their reduced precisions relative to recent geochemical analyses of similar rocks. Therefore, it is likely that comparison of data from the older and more recent analyses will be impaired by this difference in precision. To resolve this problem, we reanalyzed the archived the Shikoku Basin BABBs.

\section{Geochemical analysis methods during DSDP Leg 58 and ODP Leg 131}

The original geochemical analyses of the BABBs recovered by DSDP Leg 58 were performed by X-ray fluorescence (XRF) at the University of Birmingham, UK (Klein and Kobayashi, 1980), whereas some trace elements were analyzed by instrumental neutron activation analyses (INAA) at the CEA Saclay, Gif-sur-Yvette, France (Wood et al., 1980). Analyses of the BABBs re- 


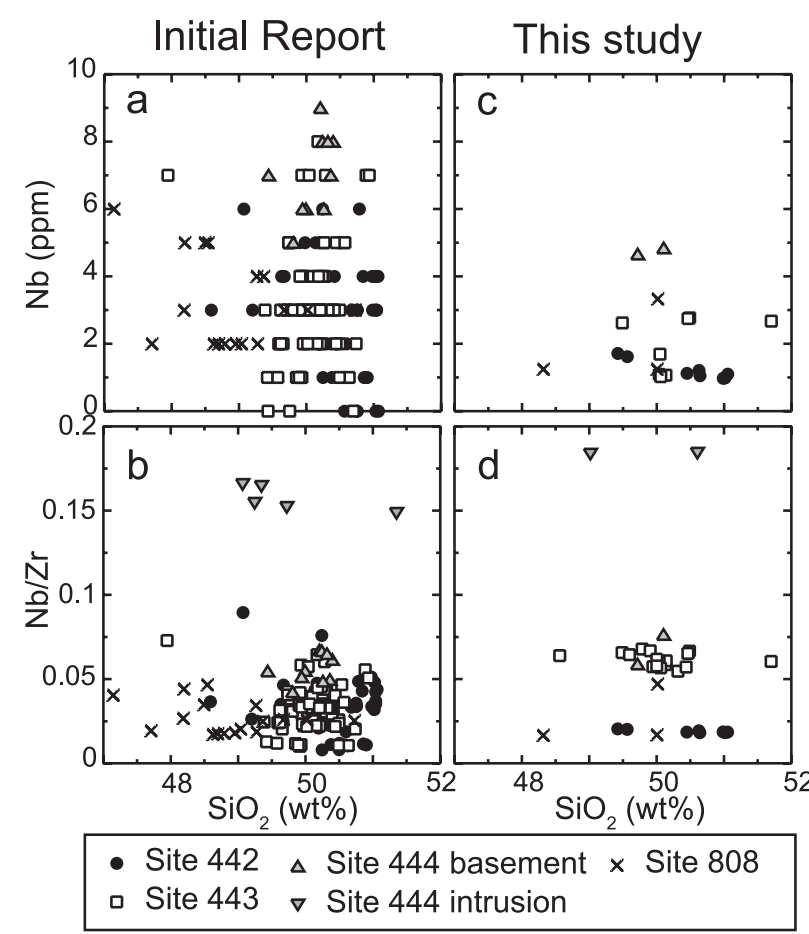

Fig. 2. Plots of $\mathrm{Nb}$ content and $\mathrm{Nb} / \mathrm{Zr}$ ratio vs. $\mathrm{SiO}_{2}$ content of the published data of the DSDP Leg 58 and ODP Leg 131 (a and b; Dick et al., 1980; Siena et al., 1993), together with data from this study (c and d). The $\mathrm{Nb}$ content in $\mathrm{a}$ and $\mathrm{c}$ is presented under $10 \mathrm{ppm}$. covered by ODP Leg 131 were performed using XRF on the D/V Joides Resolution (e.g. Shipboard Scientific Party, 1991) and at the Universities of Ferrara and Parma (Siena et al.,1993). Trace element analyses of these rocks were performed using inductively coupled plasma (ICP) atomic emission spectrometry at the Centre de Recherches Pétrographiques et Géochimiques of Nancy, France (Siena et al., 1993). These data are compiled in PetDB [URL1].

Wet chemical analysis constituted the main method of bulk chemical analysis until the 1980's, when XRF method became popular in its place because of technical improvements. Comparisons of data precision between the results of XRF and wet chemical analyses have been considered (e.g. Ishihara, 2002) and various technical approaches for the improvement of XRF analysis precision have been performed. During the 1980s, the detection limit of the trace element analyses by XRF was reported to be around $1 \sim 3 \mathrm{ppm}$, effectively a numerical value with an accuracy on the order of ppm (e.g. Tamura et al., 1989). The XRF data of Legs 58 and 131 were based on a similar technique and, when the concentration is less than $10 \mathrm{ppm}$, it is thought that the analysis precision decreases (Fig. 2a). When calculating the ratio of such elements, these data will concentrate on a specific value, which may yield an impractical comparison. This is a particularly major concern when comparing the original data with recent trace element data which
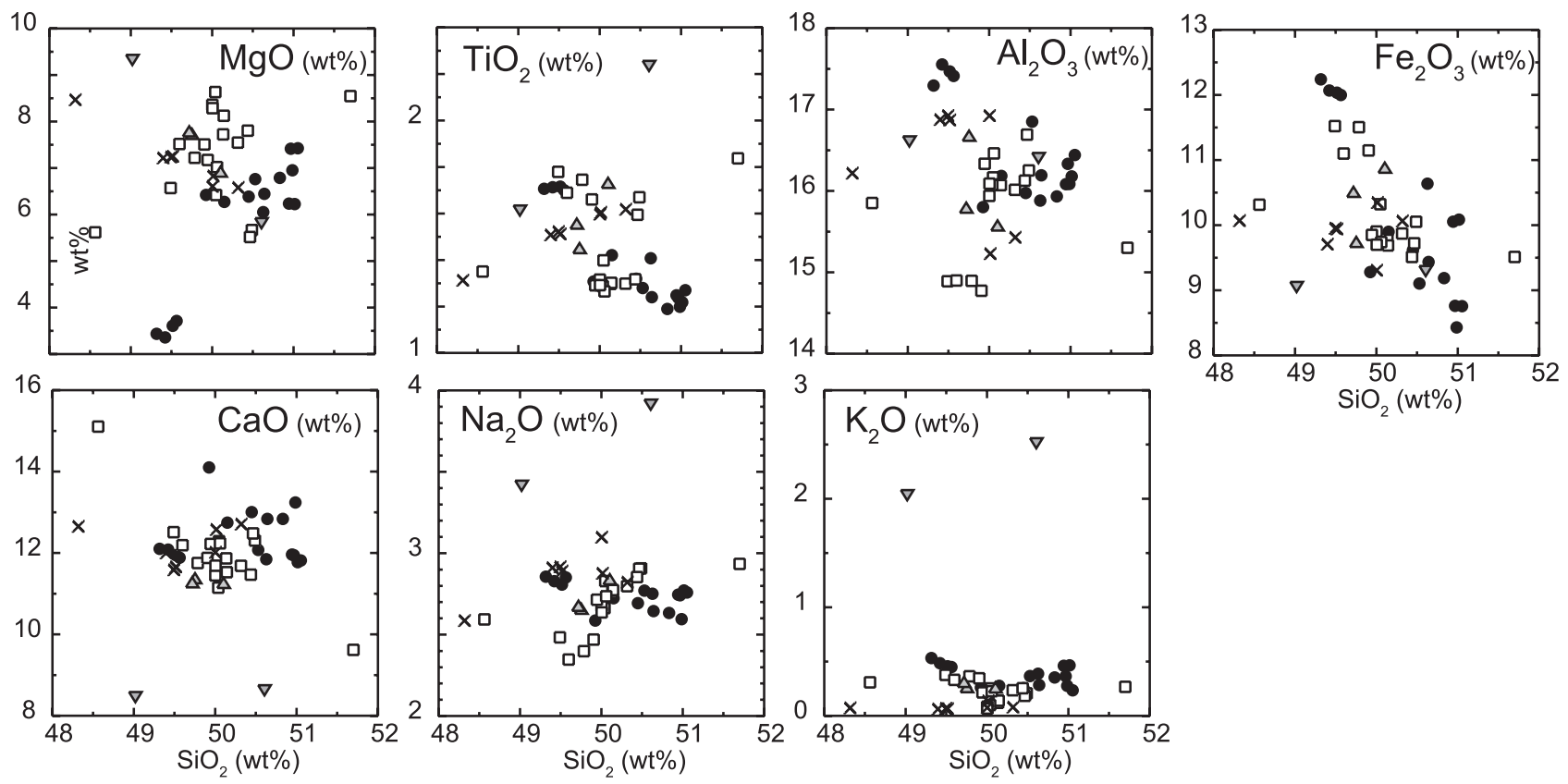

Fig. 3. Harker diagrams for samples of the DSDP Leg 58 Sites 442-444 and ODP Leg 131 Site 808. See Fig. 1 for locations. The symbols are the same as in Fig. 2. 


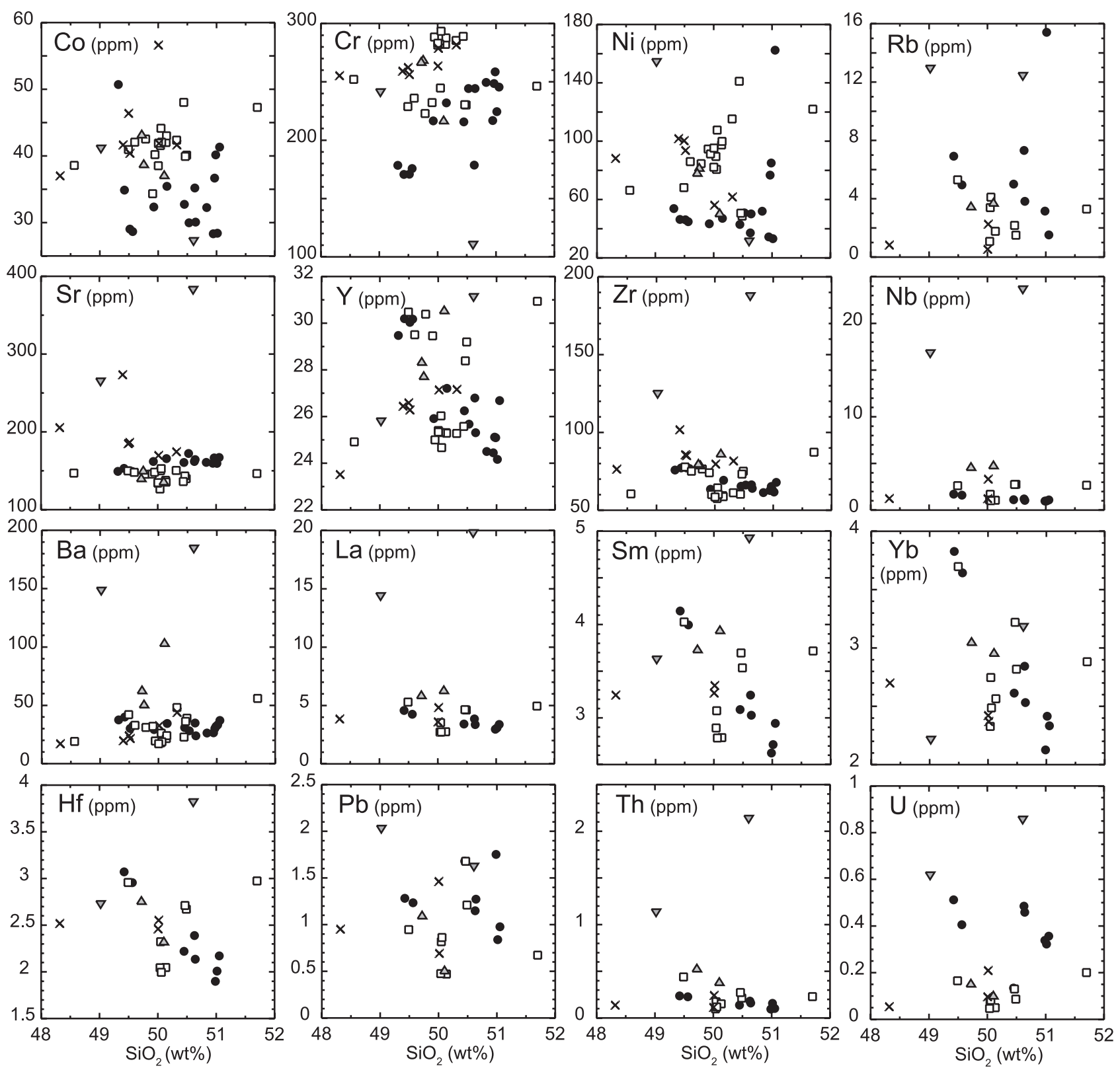

Fig. 4. Relationship between trace element concentrations and $\mathrm{SiO}_{2}$ for samples of the DSDP Leg 58 Sites $442-444$ and ODP Leg 131 Site 808. The data of Co, Cr, Ni, Sr, Y, Zr and Ba are analyzed by XRF (Appendix Table 1), and the other elements are analyzed by ICP-MS (Appendix Table 2). The symbols are the same as in Fig. 2.

has a higher precision (Fig. 2b).

\section{Results}

The archived samples of DSDP Leg 58 and ODP Leg 131 used in our analyses are stored at the Texas A\&M University. Researchers can apply for use of these archived samples using the ODP website [URL2]. A total of 46 samples were measured by a ZSX Primus II XRF spectrometer at the Atmosphere and Ocean Research Institute (AORI), University of Tokyo, 23 of which were selected for measurement by Agilent model 7500c inductively coupled plasma mass spectrometry (ICP-MS) at the Department of Systems Innovation, School of Engineering, University of Tokyo. The method of analyses is given in Appendix A and analytical results of bulk major and trace elements by XRF and ICP-MS are given in full in Appendix Tables 1 and 2.

\section{Characteristics of new data}

The highly precise analysis technique of the low concentration trace elements uses INAA and ICP-MS. Since the early 2000s, ICP-MS analysis has become convenience, and the rapid analysis of many samples is possible. Improvements in the precision of recent analyses has been aided by the technical improvement of the 

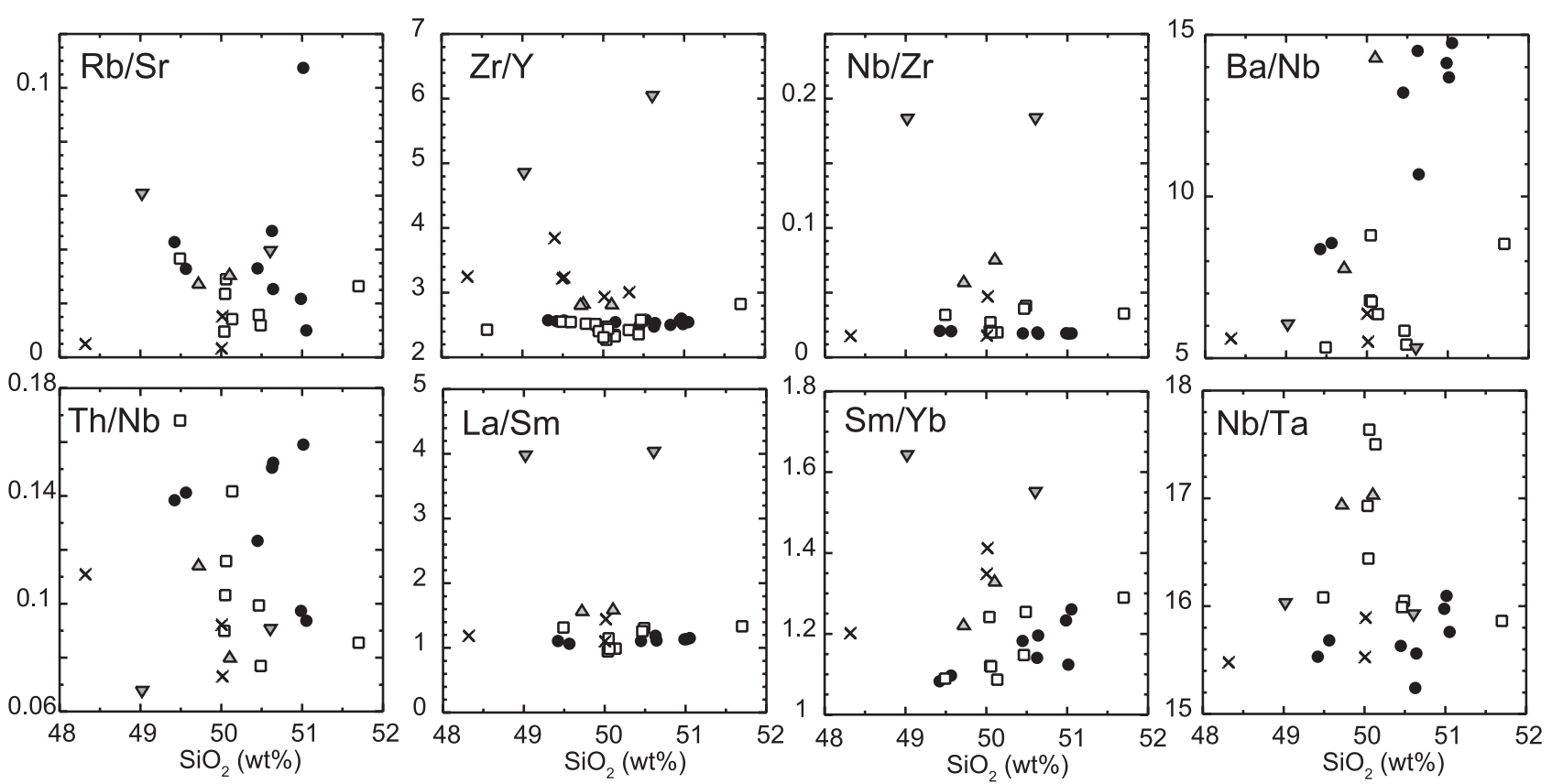

Fig. 5. Relationship between the selected trace element ratios and $\mathrm{SiO}_{2}$ for samples of the DSDP Leg 58 Sites $442-444$ and ODP Leg 131 Site 808 . The data of $\mathrm{Zr} / \mathrm{Y}$ ratio are analyzed by XRF, and the other data are analyzed by ICP-MS. The symbols are the same as in Fig. 2.

analyzer, together with the improvement of the data precision of standard samples (e.g. Kato et al., 2011). Highly precise data herein were provided by analyzing trace element concentrations using ICP-MS, and a comparison of the difference in delicate density was enabled (Fig. 2c, d). In particular, it is important that data with a precision of sub-ppm level are provided for low-concentration elements which is often argued by a density of less than $10 \mathrm{ppm}$ in subalkaline basalts of elements such as $\mathrm{Rb}, \mathrm{Nb}$ and $\mathrm{Th}$.

\section{Major and Trace Element Geochemistry}

Harker diagrams of compositional variation are shown in Fig. 3. $\mathrm{SiO}_{2}$ contents of the $\mathrm{BABBs}$ range from 48.3 to $51.7 \mathrm{wt} \%$, although most samples fall within the range of 49.2 to $51.1 \mathrm{wt} \%$. The $\mathrm{MgO}$ content of samples is generally between 5.4 and $8.7 \mathrm{wt} \%$. Some samples from Site 442 show a lower $\mathrm{MgO}$ content of 3.2 to $3.8 \mathrm{wt} \%$. These low-MgO samples also show higher $\mathrm{TiO}_{2}$ contents, about $1.7 \mathrm{wt} \%$, than other BABBs of Site 442 , which generally do not exceed $1.19-1.42 \mathrm{wt} \%$. The low-MgO samples further exhibit high $\mathrm{Al}_{2} \mathrm{O}_{3}$ and $\mathrm{Fe}_{2} \mathrm{O}_{3}$ contents, approximately 17.5 and $12 \mathrm{wt} \%$, respectively. These low-Mg and high-Ti rocks are generally found the deeper reaches of the recovered material, more than $350 \mathrm{~m}$ below the seafloor, pointed out by initial report (e.g., Dick et al., 1980). Later intrusions at Site 444 show extremely high contents of alkaline elements, particularly $\mathrm{K}_{2} \mathrm{O}$, which constitutes more than $2.0 \mathrm{wt} \%$ of later intrusions, whereas $\mathrm{BABBs}$ have comparably low content of less than $0.5 \mathrm{wt} \%$.

The relationships between trace elements and $\mathrm{SiO}_{2}$ content are shown in Fig. 4. Differences among Sites $442,443,444$, and 808 are particularly notable in the compatible trace elements: $\mathrm{Co}, \mathrm{Cr}$, and $\mathrm{Ni}$ contents are lower in rocks from Site 442 and higher in the other sites. At Site 442, differences of these trace element contents between low-MgO samples and other rocks are less apparent, as are differences between later intrusions at Site 444 and other BABBs. In terms of many incompatible trace elements and light rare earth elements (LREEs), the later intrusions show extremely high contents. On the other hand, the differences between the concentrations of these trace elements in the BABBs are obvious.

\section{Element ratios}

This reanalysis is important to allow comparison of the element ratios. A large number of significant figures were calculated for the element ratios as a result of the archived high precision of analyses (Fig. 5). Late intrusions and BABBs have different ratios of high-fieldstrength elements (HFSEs) and REEs ratios. For example, late intrusions show high $\mathrm{Zr} / \mathrm{Y}, \mathrm{Nb} / \mathrm{Zr}, \mathrm{Th} / \mathrm{Zr}$, and $\mathrm{La} / \mathrm{Sm}$ ratios. On the other hand, the differences in these element ratios among the BABBs are not obvious at all sites. 

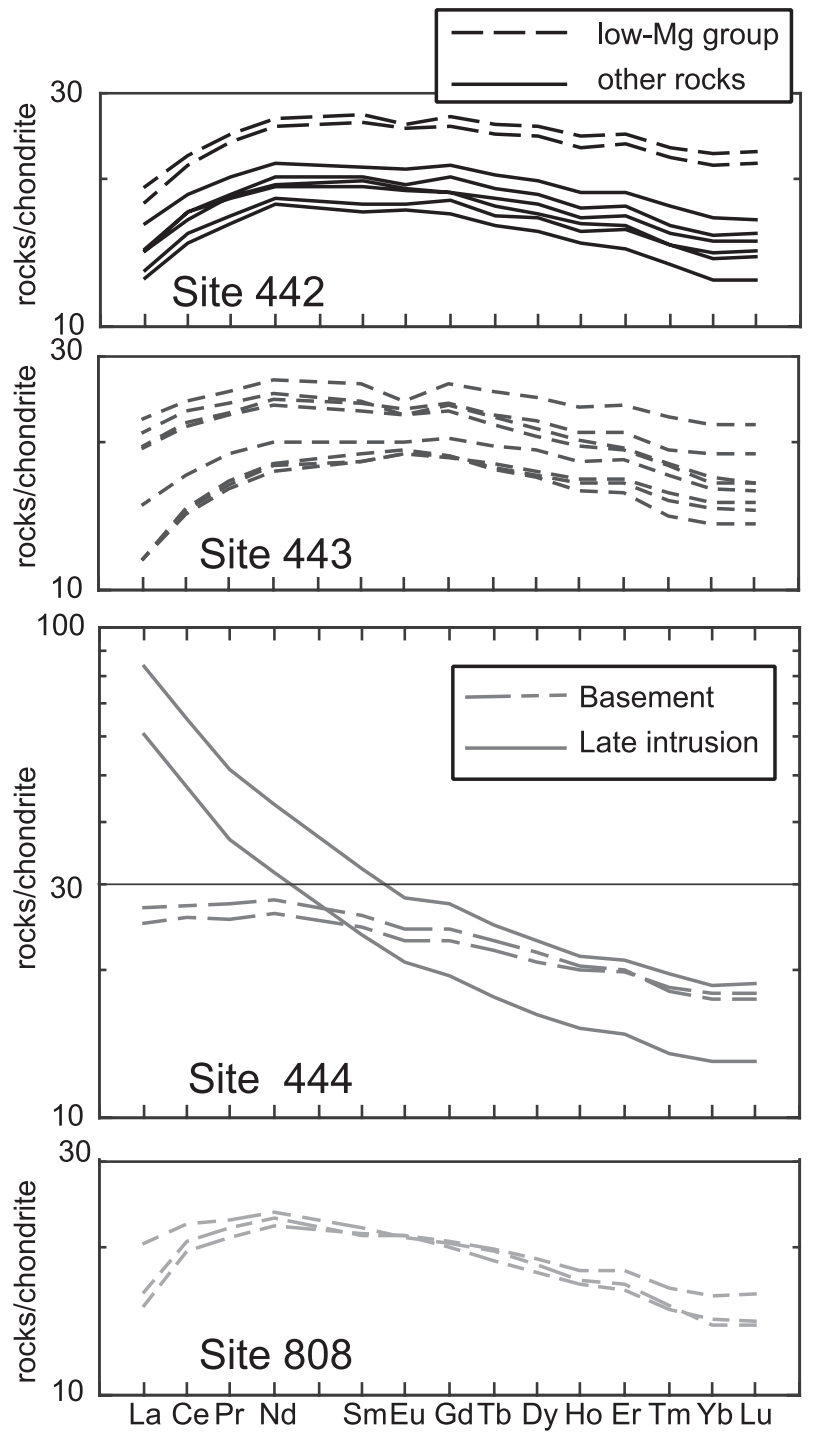

Fig. 6. Chondrite-normalized REE patterns for samples of the DSDP Leg 58 Sites 442-444 and ODP Leg 131 Site 808. Normalization values of CI chondrite are from Sun and McDonough (1989).

\section{REE patterns}

REE patterns are also important for this reanalysis since differences in such geochemical characteristics of BABBs are evident at each site (Fig. 6). The rock/chondrite ratio decreases from middle rare earth elements (MREEs) to HREEs in the BABBs. Site 808 shows the greatest decrease in this ratio, whereas the change becomes gentler, gradually, at Sites 444, 443, and 442. The highest peak of the rock/chondrite ratio is $\mathrm{Nd}$ at Sites 444 and 808, Sm at Sites 443 and 442, and Eu to $\mathrm{Gd}$ in some rocks at Site 442. The LREE patterns of the basements are flat at Site 444, but they show a decreasing trend from $\mathrm{Nd}$ to $\mathrm{La}$ at the other sites. This decrease is particularly pronounced at Sites 442 and 808 and moderate at Site 443. The low-Mg and high-Ti samples at Site 442 show a higher rock/chondrite ratio in the case of all REEs than other rocks at Site 442, whereas the late intrusions from Site 444 show extremely enriched REE patterns, which are characteristic of alkali basalts.

\section{Summary}

(1) We analyzed archived samples of basement rocks (back-arc basin basalts) from DSDP Leg 58 Sites 442-444 and ODP Leg 131 Site 808 in the Shikoku Basin. These analyses have a sufficiently high precision to be compared to similar datasets in recent publications, and mitigate the shortcomings of the original, lower precision geochemistry conducted on these rocks.

(2) The geochemical differences between the DSDP and the ODP sites in the Shikoku Basin are typically observed in patterns of REEs. The rock/chondrite ratios of MREEs to HREEs either rapidly or gradually decrease at Site $808,444,443$, and 442 . The content of LREEs from $\mathrm{Nd}$ to La decreases rapidly at Site 808, gradually at Sites 442 and 443, and is constant at Site 444 .

\section{Acknowledgements}

We are greatly indebted to the curators and staff of the Ocean Drilling Program of Texas A\&M University and Scripps Institution of Oceanography for access to the archived samples and sample preparation. We also thank Drs. Yutaro Takaya and Kazutaka Yasukawa for assistance with sample preparation and analyses by ICP-MS at the GSE, School of Engineering, University of Tokyo. Comments from Dr. Osamu Ishizuka (GSJ, AIST) and Prof. Toshiaki Shimura (Yamaguchi University) greatly improved the quality of the manuscript. The authors would like to thank Enago (www.enago.jp) for the English language review.

\section{References}

Dick, H. J. B., Marsh, N. G. and Bullen, T. D., 1980, Deep Sea Drilling Project Leg 58 abyssal basalts from the Shikoku Basin: Their Petrology and major-element geochemistry. In Klein, G. deV., Kobayashi, K. et al. eds., Init. Rep. DSDP, 58, U.S. Government Printing Office, Washington. D. C., 843-872.

Ishihara, S., 2002, Chemical characteristics of the mineralized granitoids (1): Mo and W provinces of the inner zone of Southwest Japan. Bull. Geol. Surv. Japan, 53, 657-672.*

Kato, Y., Fujinaga, K., Nakamura, K., Takaya, Y., Kitamura, K., Ohta, J.,...Iwamori, H., 2011, Deep-sea mud in the Pacific Ocean as a potential resource for rare-earth elements. Nat. Geosci., 4, 535-539.

Klein, G. deV. and Kobayashi, K, 1980, Introduction and explanatory notes, Deep Sea Drilling Project Leg 58. In Klein, 
G. deV., Kobayashi, K. et al. eds., Init. Rep. DSDP, 58, U. S. Government Printing Office, Washington D. C., 3-18.

Okino, K., Ohara, Y., Kasuga, S. and Kato, Y., 1999, The Philippine Sea: New survey results reveal the structure and the history of the marginal basins. Geophys. Res. Lett., 26, $2287-2290$.

Shipboard Scientific Party, 1991, Explanatory Notes. In Taira, A., Hill, I., Firth, J. et al. eds., Init. Rep. ODP. College Station, TX (Ocean Drilling Program), 25-60.

Siena, F., Coltorti, M., Saccani, E. and Vaccaro, C, 1993, Petrology of the basaltic rocks of the Nankai Trough basement. In Hill, I. A., Taira, A., Firth, J. V. et al. eds., Proc. ODP, Sci. Res., 131, 197-207.

Sun, S.-S. and McDonough W. F., 1989, Chemical and isotopic systematics of oceanic basalts: implications for mantle composition and processes. In Saunders, A. D. and Norry, M. J., eds., Magmatism in the Ocean Basins, Geol. Soc. Spec. Publ., 42, 313-345.

Tamura, S., Kobayashi, Y. and Shuto, K., 1989, Quantitative analysis of the trace elements in silicate rocks by X-ray fluorescence method. Earth Sci. (Chikyu Kagaku), 43, 180185 .**

Wood, D. A., Joron, J.-L., Marsh, N. G., Tarney, S. and Treuil, M, 1980, Major- and trace-element variations in basalts from the north Philippine Sea drilled during Deep Sea Drilling Project Leg 58: a comparative study of back-arcbasin basalts with lava series from Japan and mid-ocean ridges. In Klein, G. deV., Kobayashi, K. et al. eds., Init. Rep. DSDP., 58, U.S. Government Printing Office, Washington D. C., 873-894.

[URL1] PetDB, the Petrological Database, http://www.earthchem.org/petdb
[URL2] Ocean Drilling Program Scientific Operator, http:// www-odp.tamu.edu

*in Japanese with English abstract

**in Japanese

The following Appendixs are published as the open file on the JGS-website

$<$ http://www.geosociety.jp/publication/content0006.html $>$

Appendix A. Analytical Methods.

Appendix Table 1. Bulk rock composition of samples estimated using XRF for DSDP Leg 58 Sites 442-444 and ODP Leg 131 Site 808

Appendix Table 2. Bulk rock composition of samples estimated using ICP-MS for DSDP Leg 58 Sites $442-444$ and ODP Leg 131 Site 808 .

\section{(Contribution of authors)}

Satoru Haraguchi Analyzed bulk data using XRF, discussed the characteristics of data, wrote, adjusted and edited the manuscript

Koichiro Fujinaga Analyze bulk data using ICP-MS, discussed the characteristics of data

Kentaro Nakamura Analyze bulk data using ICP-MS, discussed the characteristics of data

Yasuhiro Kato Analyze bulk data using ICP-MS, discussed the characteristics of data

Asuka Yamaguchi Analyzed bulk data using XRF, Discussed the characteristics of data

Teruaki Ishii Corrected the DSDP and ODP samples, discussed the characteristics of data 